Karin Gundersen

\title{
Fra Shakespeare til Derrida: en spøkelseshistorie
}

Å lese Hamlet er å gå fra høydepunkt til høydepunkt: monologen To be, or not to be: that is the question (akt III, scene 1); fortellingen om Ofelias død: There is a willow grows aslant a brook (IV, 7); talen til hodeskallen: Alas! poor Yorrick. I knew him, Horatio (V, 1), og mange andre. De dukker opp fra århundrenes svøp, som seg selv i sitt eget språk og sin egen flertydighet, eller som et mangfold av oversettelser. Derrida har fremhevet oversettelsene som like mange måter å gjenopplive originalen på: «Det levende verket [...] hjemsøker dem som et uhåndgripelig spøkelse. Et mesterverk beveger seg per definisjon alltid på samme måte som et gjenferd.»1

Hamlet er kanskje først og fremst historien om et spøkelse. Spøkelset som setter handlingen i gang med en befaling om hevn. Frem til grensen mellom det hinsidige og de levendes verden kommer spøkelset med et påbud, et krav og en oppgave: Hamlet skal hevne mordet på sin far kongen, blod skal betales med blod. Denne gjengjeldelseslogikken er rotfestet $\mathrm{i}$ en arkaisk samfunnsorden og krever blind lydighet, men nå i en verden og på en tid (år 1600) da mennesket har begynt å tenke selv. Sønnen tar imot farens befaling som en byrde og en skjebne: The time is out of joint; O cursed spite, / That ever I was born to set it right! (I, 5), for straks å kastes ut i samvittighetskval, tvil og handlingslammelse. Hevnen utsettes, intrigen forlenges, vrenges og vris inntil Hamlet endelig dreper farens morder i en spontan handling og nærmest ved en tilfeldighet. Med en henvisning til Shakespeare-forskeren Peter Alexander beskriver Harold Bloom sammenstøtet mellom de to verdener slik:

[...] the Ghost is a warrior fit for Icelandic saga, while the prince is a university intellectual, representative of a new age. Two Hamlets confront each other, with virtually nothing in common except their names. The Ghost expects Hamlet to be a version of himself, even as young Fortinbras is a reprint of old Fortinbras. Ironically,

\footnotetext{
${ }^{1}$ Jacques Derrida, Marx' spøkelser (Spectres de Marx, Paris 1993), oversatt av Karin Gundersen. Oslo: Pax 1996, 41.
} 
the two Hamlets meet as if the Edda were encountering Montaigne: ${ }^{2}$ the Archaic Age faces the High Renaissance, with consequences as odd as any we might expect. ${ }^{3}$

Spøkelset dukker opp i første scene, første akt, på skanseverket foran Helsingør slott. Det er en kald og mørk natt - midnatt - og Bernardo holder vakt når Marcellus nærmer seg i følge med Hamlets venn Horatio, som kommer fra Wittenberg der han studerer ved universitetet. Horatio har vondt for å tro på noe som strider mot fornuften, men har gått med på å finne ut ved selvsyn om denne tingen (this thing) finnes i virkeligheten, den som Marcellus har fortalt om, og som han og Bernardo allerede har sett to ganger. ${ }^{4}$ De setter seg ned og Horatio ber Bernardo fortelle en gang til:

\section{BERNARDO}

Den siste natt

da stjernen vest for polen var nådd frem til det sted på himlen hvor den brenner nu, - det var på slaget ett -, da så Marcellus og jeg ...

\section{(Gjenferdet kommer) $^{5}$}

Det kommer «i skikkelse av Danmarks døde konge», og i full rustning. Hva gjør man når man står overfor et spøkelse? Prøver å finne ut hva det vil ved å henvende seg til det. Men ikke på hvilken som helst måte:

\section{MARCELLUS}

Snakk til det $d u$, Horatio, som er lærd. ${ }^{6}$

(Thou art a scholar; speak to it, Horatio.)

\footnotetext{
${ }^{2}$ Montaignes Essais i 1595-utgaven kom i engelsk oversettelse ved John Florio i 1603. Man vet at Shakespeare leste Montaigne, det er særlig tydelig i The Tempest, men forskere har funnet spor av Montaigne allerede i Hamlet selv om Florios oversettelse kom senere, hvilket kan forklares med at Florio var en venn av Shakespeare.

${ }^{3}$ Harold Bloom, Shakespeare. The Invention of the Human. New York: Riverhead Books 1998, 387.

${ }^{4}$ Stykket begynner på klassisk vis in medias res, det som skal utløse handlingen, har allerede meldt seg før stykket åpner.

${ }^{5}$ Hamlet, André Bjerkes oversettelse, Aschehoug 1959, 11. Engelsk «Ghost» kan gjengis på norsk med gjenferd, spøkelse, gjenganger ... Jeg kommer tilbake til hvorfor jeg foretrekker spøkelse.

${ }^{6}$ Ibid., 11.
} 
Visstnok skal spøkelser helst tilsnakkes på latin, det er eksorsismens språk. ${ }^{7}$ Latin beherskes nødvendigvis av Horatio, som har studert. Han prøver:

HORATIO

Hvem er da du som har brutt nattens fred,

og tilrant deg den krigerske gestalt

som Danmarks døde konge bar i livet?

ved himlen - jeg besverger deg: tal ut!

MARCELLUS

Det er blitt krenket.

\section{BERNARDO}

Se, det skrider bort.

\section{HORATIO}

Gå ikke! Jeg besverger deg: tal ut!

(Gjenferdet forsvinner. $)^{8}$

Vi ser at spøkelser også kan bli krenket; Horatio har snakket for hardt til det, uten den fornødne respekt. Denne tingen er både spøkelse og konge: Spøkelset kan besverges, men Kongen skal tiltales som konge. Her påkaller jeg Derrida, som sier at man må lære seg å omgås ånder, lære seg «å leve med spøkelsene, i samråd, fortrolighet eller samkvem med spøkelsene, i deres uselskapelige selskap». ${ }^{9}$ Den påfølgende natt er også Hamlet på plass for å møte spøkelset. Han lykkes i sitt samkvem med $\operatorname{det}^{10} \mathrm{og}$ får vite, på tomannshånd og $\mathrm{i}$ hemmelighet, at kongen ble myrdet av sin egen bror, som dermed fikk overta både kongeriket og dronningen. Det er under denne samtalen spøkelset kommer med befalingen om hevn: $I$

\footnotetext{
${ }^{7}$ Dette har jeg fra en fotnote i Yves Bonnefoys franske oversettelse.

${ }^{8}$ Hamlet, Bjerkes oversettelse, 12.

${ }^{9}$ Jacques Derrida, Marx' spøkelser, 22. Derrida kommenterer Horatios mislykkete henvendelse til spøkelset slik: Som tradisjonell scholar tror han ikke på spøkelser, men tvert imot på «det klare skillet mellom virkelig og ikkevirkelig, faktisk og ikke-faktisk, levende og ikke-levende, væren og ikke-væren [...] det som er nærværende og det som ikke er det» (34), og har nok også i bakhodet alle de tradisjonelle filosofene, Horatios etterkommere, som tviholder på den vestlige metafysikkens dikotomier og er blinde for de innsikter som dekonstruksjonen kan gi.

${ }^{10}$ Han tiltaler det på høvisk vis: I'll call thee Hamlet, King, father; royal Dane, O! answer me.
} 
am thy father's spirit [...] If thou didst ever thy dear father love [...] Revenge his foul and most unnatural murder (I, 5).

Hamlets dilemma (adlyde blindt eller tenke selv) er blitt kommentert og tolket på forskjellig vis opp gjennom historien. Det hittil siste svaret kom så sent som i fjor, da den relativt unge renessanseforskeren Rhodri Lewis utga boken Hamlet and the Vision of Darkness. ${ }^{11}$ Den har fått to anmeldelser nylig, i prestisjefylte fora: henholdsvis av James Shapiro i The New York Review of Books («The question of Hamlet»), ${ }^{12}$ og av Michael Dobson i London Review of Books («Elsinor's star bullshitter»). ${ }^{13}$ Lewis' tese er kort fortalt at Hamlets berømte monologer der vi kan beundre hans skarpsindige introspeksjon og selvanalyse, egentlig bare er en saus av halvfordøyde dypsindigheter, en veritabel studie i overfladisk humanisme, klisjeer og læresetninger, og simpelthen bullshit (hvorav tittelen på Dobsons anmeldelse). Hamlet er ifølge Lewis en selvopptatt guttunge som poserer og aldri har til hensikt å handle. Alt dette har Shakespeare villet vise oss og advare mot. Claudius har myrdet sin bror, men han har iallfall skjønt hva spillet går ut på, i en verden uten sikre moralske standarder, der det dreier seg om å drepe eller bli drept. To kill or be killed: Det gir mening, i motsetning til To be or not to be, som ingen, fortsatt ifølge Lewis, noensinne har skjønt hva betyr. De to nevnte anmelderne, som begge er meget lærde Shakespeare-forskere, skyter ham ned med tungt artilleri. ${ }^{14}$ Likevel unnlater de ikke å kreditere Lewis med enkelte treffende poenger. Shapiro har dessuten tatt seg bryet med å finne frem en tekst som Lewis har publisert på internett, der han fremholder at nettopp nå, «in Trumpland and on Brexit Island», er Shakespeare blitt viktigere enn noensinne fordi han i Hamlet viser at verden alltid har vært amoralsk og blodtørstig, mens våre ideer om en moralsk orden er ren staffasje. Det må innrømmes at i mørke stunder ser det slik ut. Betyr det at spøkelset har rett, at det er i sin rett, og at all lærdom, selv når den er annammet og langt fra overfladisk, er bortkastet strev? Må vi virkelig velge mellom spøkelser og et rikt intellektuelt liv?

Her må Derrida få komme inn på scenen, han som sier at vi må lære oss å omgås ånder. Det vil si, han trer inn og opptrer helt av seg selv, i åpningen av Marx’ spøkelser:

Noen, du eller jeg, går frem og sier: Jeg skulle gjerne laere å leve egentlig.

\footnotetext{
${ }^{11}$ Princeton University Press 2017.

12 19. april 2018.

13 13. september 2018.

${ }^{14}$ Som en bonus får vi i Dobsons anmeldelse en helt spesiell frukt av hans omfattende lærdom: Hamlet ble umåtelig populært allerede fra begynnelsen av, det ble satt opp overalt og gjerne av studentteatergrupper. Dessuten, i en oppsetning av Orestien på Christ Church i Oxford i 1614 var det lagt inn lange sitater fra Hamlet, og på et visst tidspunkt dukker Agamemnon opp som spøkelse og krever å bli husket og hevnet. Dette for det tilfelle, sier Dobson, at noen skulle ha gått glipp av likhetene mellom Orestien og Hamlet.
} 
Hvorfor, egentlig?

Lcere å leve. En merkelig parole. Hvem kan lære det? Av hvem? ${ }^{15}$

Derrida taler her i rettferdighetens navn, der hvor den ennå ikke er eller ikke lenger er, ettersom «lære å leve» uttrykker et engasjement og en moral. Ansvar og ansvarlighet må tenkes i det levende nærværs ikke-samtidighet med seg selv som respekterer de som ikke er nærværende, døde og ennå ikke fødte. Dermed må vi lære å omgås spøkelser. Vi gjenkjenner spøkelset i Hamlet som krever rettferdighet. Og som gjentatte ganger gjentar Hamlets befaling til de andre tilstedeværende, de som har sett spøkelset, om at de må sverge ved hans sverd på at de ikke skal røpe for noen hva de har sett, men bevare hemmeligheten. Derrida siterer fra denne scenen ${ }^{16}$ før han påkaller enda et berømt spøkelse, nemlig det som åpner Det kommunistiske partis manifest:

Jeg visste vel at et spøkelse ventet på meg der, helt fra åpningen av, idet teppet går opp [...]: Ein Gespenst geht um in Europa - das Gespenst des Kommunismus. ${ }^{17}$

Den hittil siste norske oversettelsen ${ }^{18}$ gjengir denne setningen slik: «Et gjenferd går omkring i Europa - kommunismens gjenferd.» Jeg ville ha foretrukket «spøkelse» for «Gespenst», heller enn «gjenferd», fordi et gjenferd går igjen, det er noe(n) som har vært levende og kommer tilbake, mens et spøkelse kan være både et gjenferd og et ondt varsel, altså rettet mot fremtiden. Denne dobbeltheten er tilfelle i Hamlet (I, 1): «HORATIO: Hva dette varsler, vet jeg ikke sikkert, / men tror nok at det bærer bud om uro / og sterke rystelser for dette land.» Mens det er bare den siste betydningen som er virksom i Manifestet, der kommunismen er noe som skal komme, ${ }^{19}$ som «alle makter i det gamle Europa» oppfatter som truende og «har forent seg i en hellig klappjakt på». Det er som skremsel, «bud om uro og sterke rystelser» (Hamlet), at dette vesenet som åpner Manifestet, får sin profetiske kraft, som trussel (om opprør, hevn og krav om rettferdighet på vegne av utallige undertrykte) at det må tas alvorlig, som et ekte spøkelse: «Måtte de herskende klasser skjelve ved tanken på en kommunistisk revolusjon.» ${ }^{20}$

\footnotetext{
${ }^{15}$ Derrida har en klar sans for dramaturgi, han iscenesetter gjerne både seg selv og andre filosofer, henter dem inn og lar dem fremføre sine replikker, utspør og forhører dem der de står i rampelyset. Dette grepet, som fungerer aller best live, på en scene eller et podium, kan forklare noe av suksessen med hans fire-fem timer lange forelesninger, som et intenst oppmerksomt publikum aldri syntes å gå lei av.

${ }^{16}$ Jacques Derrida, Marx’ spøkelser, 25.

${ }^{17}$ Ibid., 26.

${ }^{18}$ Ved Leif Høghaug. Oslo: Sentralkomiteen 2016.

${ }^{19}$ Også poengtert av Derrida, Marx' spøkelser, 60.

${ }^{20}$ Det kommunistiske partis manifest, 69.
} 
For å forstå spøkelset må vi tenke det i sin spøkelsesmessighet. Dette er hantologien, som er Derridas nyord for hjemsøkelsens logikk. Mens ontologien er læren om det som er, er hantologien læren om det som verken er eller ikke er. Et spøkelse har det med å bevege seg på uberegnelig vis; det holder seg aldri på plass, på sitt sted, men snakker fra stadig nye steder, som i Hamlet når det skal sverges. Da er det blitt usynlig og lar sin stemme lyde fra under jorden («Sverg!», først her, så der, hic et ubique (her og overalt), som Hamlet kommenterer. Adskiltheten i nåtidens nærvær, ikke-samtidigheten med seg selv som preger det nærværende nå, er den radikale utidighet eller anakroni som spøkelset må tenkes ut fra. Nåtiden foregår i den midlertidige passeringen, i ustadigheten mellom det som går (fortid) og det som kommer (fremtid). ${ }^{21}$ Spøkelset er ikke-samtidig og ikke-identisk med seg selv. Det er «frekvensen til en bestemt synlighet. Men det usynliges synlighet.» ${ }^{22}$ Hantologien er, som man kanskje har gjettet, en ny betegnelse for dekonstruksjonens berømt-beryktete term «différance»: forskjellighet, adskillelse og utsettelse av mening, med utgangspunkt i språkets konstituering som vev av forskjeller. ${ }^{23}$

Marx er død, ${ }^{24}$ men spøkelset hans fortsetter å snakke. ${ }^{25}$ Blant marxismens forskjellige «ånder» fremhever Derrida det messianske, en dimensjon han alltid var opptatt av, og særlig i sin siste, etisk-politiske fase. Det messianske hos Marx er rettferdigheten som skal komme, men Derrida distanserer seg fra forestillingen om idealsamfunnet som historiens slutt og det nærvær som skal komme og forbli seg selv i ontologisk forstand. Det messianske uten messianisme i Derridas forstand er formelen for et håp, en måte å tenke på som åpner for det uventete, selve hendelsen, en hendelse som kanskje aldri kommer og i hvert fall ikke på den måten vi tror. Dette må også gjelde demokratiet, gitt at alle demokratier i en viss forstand er mislykkete sett fra avstanden mellom fakta og demokratiets ideelle essens: «Det er grunnen til at vi stadig anbefaler å tale om et demokrati som skal komme, ikke et fremtidig demokrati, i

\footnotetext{
${ }^{21}$ Jacques Derrida, Marx’ spøkelser, s. 47-48 (jeg parafraserer).

${ }^{22}$ Ibid., 124.

${ }^{23}$ Litt mer presist kan vi la Derrida si det selv, i den grunnleggende artikkelen «Différance»: «Idet vi fastholder skjemaet, om ikke innholdet i det krav Saussure formulerer, vil vi med différance betegne den bevegelse i henhold til hvilken språket, eller hver kode og hvert henvisningssystem generelt, «historisk» konstitueres som vev av forskjeller.» Jacques Derrida, Dekonstruksjon. Klassiske tekster i utvalg, oversatt av Karin Gundersen. Oslo: Spartacus 2006, 109.

${ }^{24}$ Marx og marxismen døde kanskje med kommunismens fall i 1989, det er iallfall hva mange ville ha det til, og «dødsfallet» ble feiret av nyliberalistiske predikanter som Francis Fukuyama, i hans bok The End of History and the Last Man (1992). Derrida bruker store deler av Marx’ spøkelser til å polemisere mot Fukuyama, bl.a. ved å minne om alle «landeplagene» vi fremdeles står overfor og som tyder på at vi slett ikke er kommet til historiens slutt og den liberale verdensordens idealsamfunn. Man kan si at Fukuyama ikke var verdt å bruke krefter på, det er han heller ikke i dag, men der og da ble han av mange oppfattet som en viktig tenker, og av Derrida som en bedrager som måtte avsløres.

${ }^{25}$ I bokens tittel, Marx' spøkelser, ligger både de spøkelsene som Marx var opptatt av, og de som dukker opp etter ham, der han går igjen som forskjellige varianter av marxismens ånd.
} 
fremtidsnåtid, heller ikke om demokrati som regulativ idé i kantiansk forstand eller som utopi - iallfall for så vidt som deres uoppnåelighet likevel ville ha en fremtidsnåtid som tidsform, det levende noervers fremtidige modalitet. ${ }^{26}$

Det uforbeholdent åpne i denne bevegelsen mot og henvendelsen til det som skal komme, innbefattet uberegneligheten og det anti-kalkulerende som følger av åpenheten, gjenfinner vi i andre paradoksale og aporetiske logikker som Derrida har utforsket. Det gjelder både gaven, tilgivelsen og gjestfriheten. For å unnslippe gaveutvekslingens transaksjonsøkonomi slik den er beskrevet av Marcel Mauss, ${ }^{27}$ der hele samfunn risikerer ruin fordi de skal overgå hverandre med å gi stadig dyrere gaver, må ikke gaven fremstå som gave, hverken for giver eller mottaker. Å identifisere noe om en gave ødelegger gaven. ${ }^{28} \mathrm{En}$ lignende logikk gjenfinnes i spørsmålet om tilgivelse: Det tilgivelige er det enkelt å tilgi, det krever ingen stor anstrengelse og vil til og med føles godt. Det eneste etisk relevante er å tilgi det utilgivelige, som også kan fremstå som dypt umoralsk (forstå, men ikke tilgi, pleier vi å si i de ekstreme tilfellene). Og hva gjestfrihet angår, må den være absolutt og omfatte også de fremmede som kommer. Vi kan risikere at gjesten overtar alt vi eier og kaster oss ut av vårt eget hus, men hvis vi skal forsikre oss mot dette, snakker vi ikke lenger om gjestfrihet, men en trygg og hyggelig omgangsform.

Spøkelsene skal vi ta imot, selv om vi ikke kan vite hva de vil oss. Den absolutte gjestfriheten gjelder også for dem. Derrida ville ha funnet belegg for dette i Hamlet, men han må ha oversett det. Jeg siterer fra scenen der alle må sverge i spøkelsets «nærvær»:

HORATIO

O day and night, but this is wondrous strange!

HAMLET

And therefore as a stranger give it welcome.

There are more things in heaven and earth, Horatio,

Than are dreamt of in your philosophy.

\footnotetext{
${ }^{26}$ Jacques Derrida, Marx'spøkelser, 88.

${ }^{27}$ Marcel Mauss, Essai sur le don. Forme et raison de l'échange dans les sociétés archaïques, 1925.

${ }^{28}$ Jacques Derrida, Donner le temps. Paris: Galilée 1991.
} 
Hils spøkelset velkommen som en fremmed, sier Hamlet. ${ }^{29}$ Når denne oppfordringen er blitt nærmest usynlig, selv for én som ønsker spøkelser velkommen, må det være fordi den etterfølges av det ekstremt berømte og til stadighet siterte dictum: There are more things in heaven and earth, osv. Det skinner med et lys som legger omgivelsene i mørke.

Det er ikke lenger, ikke i vår tid, og ikke hvis man løsriver seg fra den tradisjonelle lærdommen der hvitt er hvitt og svart er svart, og alt er identisk med seg selv, ikke lenger umulig å snakke med spøkelser selv om man er en scholar. Antagonismen mellom spøkelsets arkaiske struktur og kompleksiteten i Hamlets sinn er avskaffet. Vår tids Horatio kan få tilgang til begge, slik lyder Derridas konklusjon og siste ord:

Iallfall hvis han elsker rettferdigheten, bør fremtidens «lærde», morgendagens «intellektuelle», lære seg det, og av ham [spøkelset]. Han burde lære å leve, ikke ved å føre en konversasjon med spøkelset, men ved å samtale med det, med ham eller henne, la det få beholde eller få tilbake ordet, om det så var i en selv, i den andre, i den andre i en selv: De er hele tiden der, spøkelsene, selv om de ikke eksisterer, selv om de ikke er mer, selv om de ennå ikke er. De gir oss dette «der» å tenke gjennom på ny straks man åpner munnen, selv på et seminar ${ }^{30}$ og særlig når man taler et fremmed språk: «Thou art a scholar; speak to it, Horatio»... ${ }^{31}$

\footnotetext{
${ }^{29}$ Spillet på «strange» (underlig) og «stranger» (fremmed) er ganske uoversettelig til norsk. André Bjerke har skrevet det om til det ganske ugjenkjennelige: «Det er som en merkverdig drøm. / Så hils det da velkommen som en drømmer.» (Hamlet, 59)

${ }^{30}$ Utgangspunktet for Marx' spøkelser var et seminar ved University of California (Riverside), der Derrida måtte forelese på engelsk, «et fremmed språk».

${ }^{31}$ Jacques Derrida, Marx'spøkelser, 199.
} 